\title{
Morphological and histological study of the forewing of Aleyrodes proletella (Linnaeus 1758) (Sternorrhyncha, Hemiptera) with a comparative analysis of forewings among Sternorrhyncha infraorders
}

\author{
Barbara Franielczyk-Pietyra' ${ }^{1} \cdot$ Łukasz Depa $^{1} \cdot$ Piotr Wegierek $^{1}$
}

Received: 16 January 2019 / Revised: 10 May 2019 / Accepted: 14 May 2019 / Published online: 29 May 2019

(c) The Author(s) 2019

\begin{abstract}
Identification of whiteflies is based mainly on larval stages and generally very little is known about wings of these insects. Therefore, both sides of the forewings of Aleyrodes proletella were studied using histological methods, light and scanning electron microscopes. Studies confirm the occurrence of only three veins on forewings: the costal, radial and anal ones; only the anal vein lies under the anal fold. A campaniform and trichoid sensilla are present. The shape of wax secretions and wing margins is described. The comparative analysis of forewing structures contains new data for all Sternorrhyncha infraorders. The current results confirm the monophyly of the group, but place aphids closer to psyllids. The analysis of forewing base indicates that its general model is similar among Sternorrhyncha, but there occur some intergroup differences. Ways of wing folding depend on the structure of thorax.
\end{abstract}

Keywords Forewing morphology $\cdot$ Wing veins $\cdot$ Cross section $\cdot$ Aleyrodids $\cdot$ Sternorrhyncha

\section{Introduction}

Sternorrhyncha is a Hemiptera suborder divided into four infraorders: Psyllomorpha (jumping plant-lice), Aleyrodomorpha (whiteflies), Aphidomorpha (aphids) and Coccomorpha (scale insects) (Heie and Wegierek 2009). Morphological studies have indicated that these hemimetabolous insects are a monophyletic group consisting of sister groups of aphids + coccoids and psyllids + aleyrodids (Hennig 1981; Carver et al. 1991).

The studied whitefly species, Aleyrodes proletella (Linnaeus 1758) (Fig. 1a, b) is a small insect belonging to the Aleyrodidae family. This family comprises mostly extant subfamilies (Evans 2007). Due to the strong wax covering

Electronic supplementary material The online version of this article (https://doi.org/10.1007/s00435-019-00449-1) contains supplementary material, which is available to authorized users.

Barbara Franielczyk-Pietyra

barbara.franielczyk-pietyra@us.edu.pl

Department of Zoology, Faculty of Biology and Environmental Protection, University of Silesia, Bankowa 9, 40-007 Katowice, Poland representatives of Aleyrodidae are also named whiteflies. They resemble tiny moths, which was probably the reason why Linnaeus in 1758 included A. proletella into that group (Martin et al. 2000). Like other Sternorrhyncha representatives, whiteflies are plant sap-sucking pests. Fossil inclusions can only be found in amber (Drohojowska and Szwedo 2015; Szwedo and Drohojowska 2016).

Whitefly identification keys have been based on the characteristics of larval stages (Hodges and Evans 2005). As a result, rarely have the imagines of whiteflies been investigated. Sexual dimorphism among adult specimens is demonstrated in differences in genitalia, the number of ventral abdominal wax plates and in a smaller size of males. These features tend to be mentioned only in supplements to the keys describing the larval stages of aleyrodids (Hodges and Evans 2005). However, Drohojowska and Szwedo (2015) studied fossil whitefly genera from Lebanese amber and showed some diagnostic features for the adult stage. These authors, as well as Martin (2007), emphasized that there is a lack of descriptive characters of adult whiteflies, which limits descriptive and comparative work between fossils and extant taxa. Wing venation is often used in the systematics of whiteflies (Shcherbakov 2000; Martin 2007). 

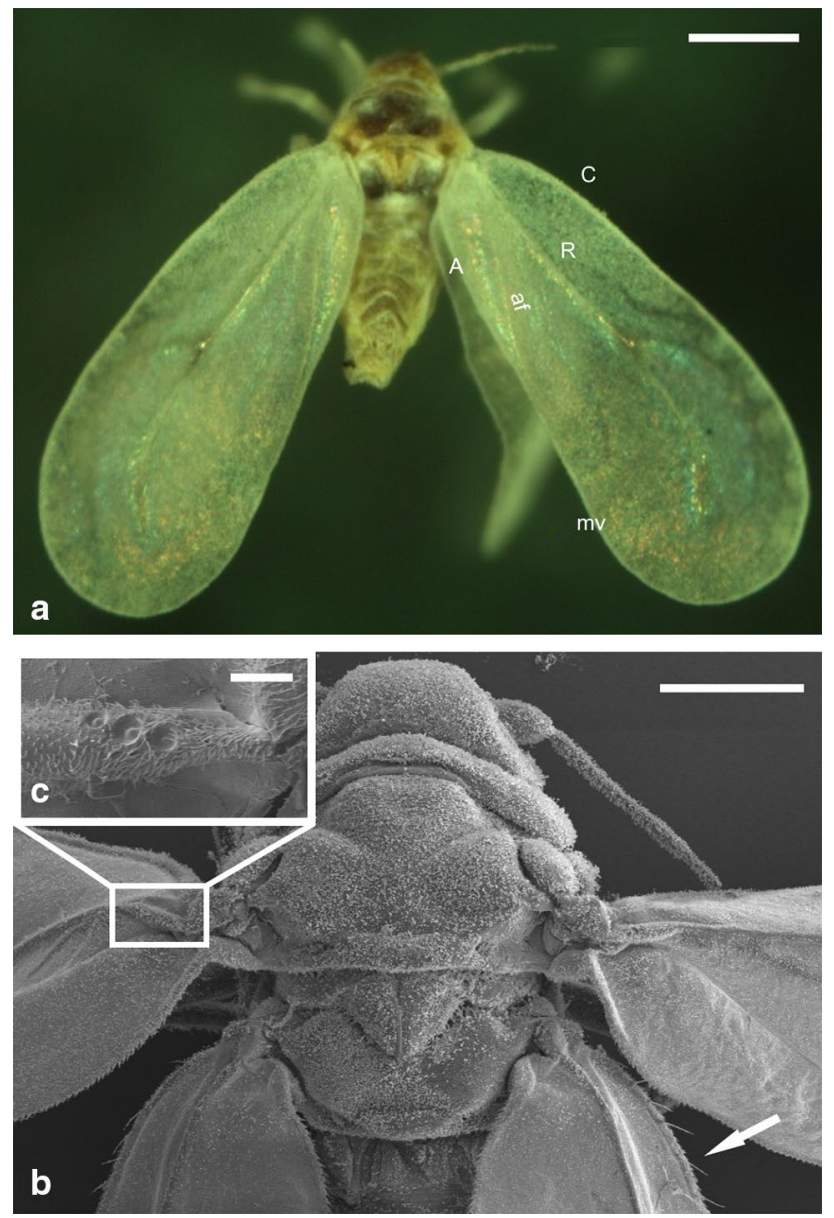

Fig. 1 a Light microscopy (LM): the forewing of Aleyrodes proletella (Linnaeus 1758), veins organization, dorsal view. Scale bar $250 \mu \mathrm{m}$, b Scanning electron microscopy (SEM) showing a row of 7 hairs on the costal margin of the hindwing (white arrow). Scale bar $150 \mu \mathrm{m}, \mathbf{c}$ Scanning electron microscopy showing campaniform sensilla at the beginning of radial vein. Scale bar $20 \mu \mathrm{m}$

Information on forewing venation in aleyrodids can be found in Patch (1909), Schlee (1970), Szelegiewicz (1971), Klimaszewski and Wojciechowski (1992) as well as Shcherbakov $(2000,2007)$. Patch studied both wing venation and tracheation. Other authors introduced some mostly theoretical modifications of venation.

It is the last part of the research on forewings in Sternorrhyncha representatives. The whole series was undertaken to verify the following hypotheses:

1. Morphologically flight apparatus does not differ much among Sternorrhyncha infraorders.

2. Forewing external veins reflect their internal structure.

3. The way of wing folding (flat or roof-like) in Aphidomorpha infraorder is correlated with the structure of wing base.

\section{Materials and methods}

\section{Scanning electron microscopy (SEM)}

Forewings of $A$. proletella species were examined using scanning electron microscopy. Samples were fixed and stored in $70 \%$ ethanol and then prepared using ethanol dehydration and hexamethyldisilazane (HMDS) drying. After $70 \%$ ethanol fixation, material was dehydrated in a graded ethanol/water series of $75 \%, 80 \%, 90 \%, 96 \%$ and $100 \%$ for $10 \mathrm{~min}$ in each concentration and then there were three $100 \%$ ethanol changes. After dehydration, samples were treated with HMDS $3 \times 10$ min and remained in HMDS after third change until the solution evaporated (Kanturski et al. 2015). Because of their high sensitivity, wings were not cleaned before SEM examination. Any cleaning attempt resulted in wings damage or curling (Franielczyk-Pietyra, not published). It was difficult to avoid damages of wings even while using alcohol series.

Samples were mounted on holders, sputter-coated with gold and examined using a scanning electron microscope Hitachi UHR FE-SEM SU 8010 (Tokyo, Japan) in the Scanning Electron Microscopy Laboratory at the Faculty of Biology and Environmental Protection, University of Silesia.

\section{Histology}

Specimens were collected to $70 \%$ ethanol and then transferred to $2.5 \%$ glutaraldehyde in a $0.05 \mathrm{M}$ cacodylate buffer ( $\mathrm{pH}$ 7.4). After washing in a $0.1 \mathrm{M}$ phosphate buffer ( $\mathrm{pH} 7.4$ ), the material was postfixed for $2 \mathrm{~h}$ in $1 \% \mathrm{OsO}_{4}$ in a phosphate buffer, dehydrated in a graded series of ethanol replaced by acetone and then embedded in an Epoxy Embedding Medium Kit (Sigma, St. Louis, MO). Semithin sections were cut from the root to the tip of the forewing on a Leica Ultracut UCT ultramicrotome (each section having a thickness of $700 \mathrm{~nm}$ ) with diamond knife and stained with methylene blue.

Sectional cuts (Fig. 2) were analyzed using Nikon eclipse E600 light microscope and photographed with a Nikon DS-Fi2 camera. The whole wing was cut into about 700 semithin sections, from which 12 slices were selected after very thorough examination. We divided the wing for 12 sections on the course of the veins. The most damaged sections were rejected. Sections are aligned in Figs. 3 and 4 in accordance with the white lines on SEM images (costal margin at the top, anal margin at the bottom, upper surface to the right). Some slices were positioned at the angle to use the available space efficiently.

As the nomenclature of veins is still non-consistent, we decided to adopt that of Shcherbakov (2007), Szwedo 


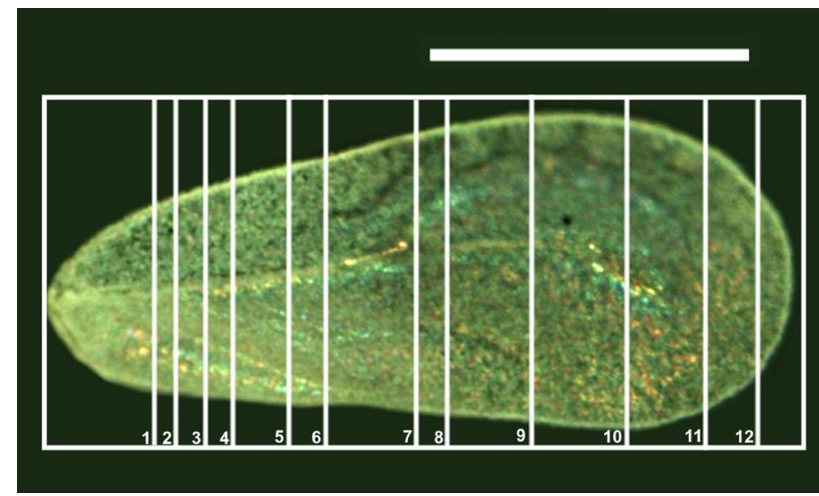

Fig. 2 Light microscopy: the forewing of Aleyrodes proletella (Linnaeus 1758), places of sectional cuts. Scale bar $500 \mu \mathrm{m}$

and Nel (2011) as well as Nel et al. (2012). The following abbreviations are used in figures and in the text: af - anal fold; alf-fold of anal lobe; anwp-anterior notal wing process; axc2—axillary cord; br-basiradiale; brb-basiradial bridge; bsc_-basisubcostale; dmp—distal median plate; hp-humeral plate; $\mathrm{m}$-mesonotum; mnwpmedian notal wing process nt 1 - pronotum; pmp-proximal median plate; pnwp-posterior notal wing process; ppt—parapterum; prb—prealar bridge; psc2—praescutum; pwp-posterior wing process; sc2-mesoscutum; scl2mesoscutellum; tg-tegula; $1 \mathrm{Ax}, 2 \mathrm{Ax}, 3 \mathrm{Ax}$-axillary sclerites 1, 2, 3; A-anal vein, $\mathrm{C}$-costal vein; $\mathrm{M}$-medial vein; $\mathrm{M}_{1}, \mathrm{M}_{2}$-the first and second branch of medial vein; $\mathrm{M}_{1+2}$ - fused first and second branch of medial vein; $\mathrm{M}_{3+4}$-fused third and fourth branch of medial vein; $\mathrm{mv}$ marginal vein; $\mathrm{pt}$ - pterostigma; $\mathrm{PCu}$ - postcubital vein; $\mathrm{R}$-radial vein; $\mathrm{R}_{1}(=\mathrm{RA})$ - the first branch of radial vein (= radius anterior); Rs $(=\mathrm{RP})$ - radius sector (= radius posterior); $\mathrm{Sc}$-subcostal vein; $\mathrm{Cu}$-cubital vein, $\mathrm{CuA}_{1}$, $\mathrm{CuA}_{2}$ - the first and second branch of cubital vein; "cua", "cup", "ms", "rs"- transparent patches on the wing membrane in places of $\mathrm{CuA}, \mathrm{CuP}, \mathrm{Ms}$ and Rs veins.

No special protocols or legal requirements of our country were needed to conduct this research.

\section{Comparative analysis}

Fifty-three characters from forewing veins, wing base sclerites, wing coupling apparatus and additionally from the head and thorax (Wegierek 2002, modified) were coded (A1). The character matrix was created using Mesquite ver. 2.71 (Maddison and Maddison 2009). The matrix (A2) included 53 features for 5 taxa, where " 0 " means primitive character state (plesiomorfic; occurring in the outgroup). Digits "1", "2" and " 3 " indicate a changed state, based on ingroup as well as outgroup morphological comparison. The analyses were designed with TNT 1.5 software (Goloboff and Catalano
2016) using the "Traditional Search" algorithm to find the most parsimonious trees. The following parameters were used: "memory set—10,000 trees"; "tree bisection—reconnection (TBR) branch-swapping algorithm" with "10 replications", "saving 100 trees per replicate" and "zero-length branches collapse after the search". The consensus tree was calculated using the "majority rule consensus" method with a cutoff threshold of $50 \%$. All multistate characters were treated as unordered and equally weighted. The trees and features were studied using WinClada ver. 1.00.08 (Nixon 2002) and graphical processing was performed using Paint. NET 4.0.9.

\section{Results}

\section{SEM}

There are two types of exteroreceptors on the dorsal side of forewing - campaniform and trichoid sensilla. The former are cuticular processes (Fig. 5a) which are usually grouped and found near the joints at the wing base. There are several campaniform sensilla at the beginning of radial vein (Fig. 1c) and some along the course of this vein (Fig. 5b). The latter are bristles (b, Fig. 5c) growing out of cuticle and being surrounded by a high socket (so, Fig. 5c). There are only a few sensilla of this kind on the dorsal wing surface.

Both upper and lower wing surfaces are covered with a dense wax layer. The wax is in the form of small, snail-like rings (w, Fig. 6a). There are microtrichia on both wing sides (mt, Figs. 5c, 6a). Along the entire forewing, a thickened margin is present. It is composed of tuberous elements covered with microtrichia (Fig. 6b).

Pterostigma is absent.

On the costal margin of hindwing, a row of about 7 stout hairs is present (Fig. 1b, white arrow).

\section{Cross section of the forewing}

All sections contain the costal vein-it is clearly visible throughout its entire course (Figs. 3a-f, 4a-e). The second conspicuous vein, in the form of a convex common stem, is rather wide in section (Fig. 3a, b) suggesting that there may be more than one vein inside. However, this vein is not divided. What is more, it looks like a single vein in wing membrane on the third cut (Fig. 3c); it is convex and very small in section. Therefore, it is marked as the radial vein only (R, Figs. 3a-f, 4a-d). Under this vein, there lies a concave anal fold (af, Fig. 3a-f), which extends to one-third of the wing length. As long as the anal fold is visible, the anal vein is present (A, Fig. 3a-f). When the anal fold becomes obsolete, only a small marginal vein (mv, Fig. 4a-e) can be recognized at the anal margin. On the last section (Fig. 4f), 

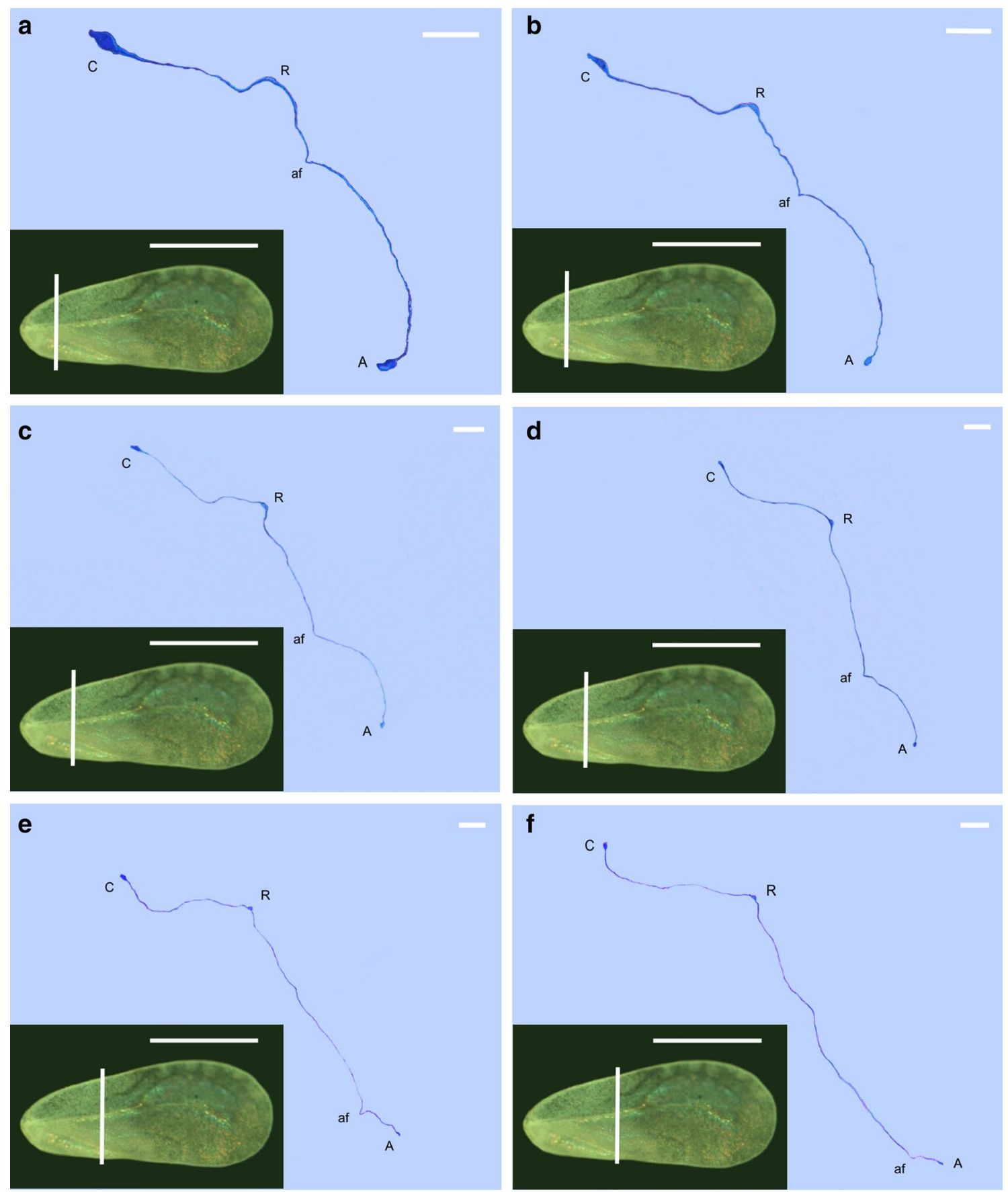

Fig. 3 Cross sections of the forewing of Aleyrodes proletella (Linnaeus 1758). LM scale bar $=500 \mu \mathrm{m}$. SEM scale bar $=50 \mu \mathrm{m}$

both the costal and anal margins are thickened but do not contain any vein.

\section{Phylogenetic analysis}

The parsimony analysis resulted in 2 most parsimonious trees ( $\mathrm{L}=58$ steps); the strict consensus tree is presented in Fig. 9. The Sternorrhyncha suborder was retrieved as a monophyletic group, where aphids + psyllids, as well as coccoids + aleyrodids turned out to be sister groups. The first group (aphids + psyllids) is a monophyletic group exhibiting seven synapomorphies: 8(1): first and second branch of medial vein fused $\left(\mathrm{M}_{1+2}\right) ; \mathbf{9 ( 1 )}$ : third and fourth branch of medial vein fused $\left(\mathrm{M}_{3+4}\right) ; \mathbf{1 2}(\mathbf{1})$ : first branch of cubital anterior vein $\left(\mathrm{CuA}_{1}\right)$ present; 13(1): second branch of cubital anterior vein $\left(\mathrm{CuA}_{2}\right)$ present; 21(1): 

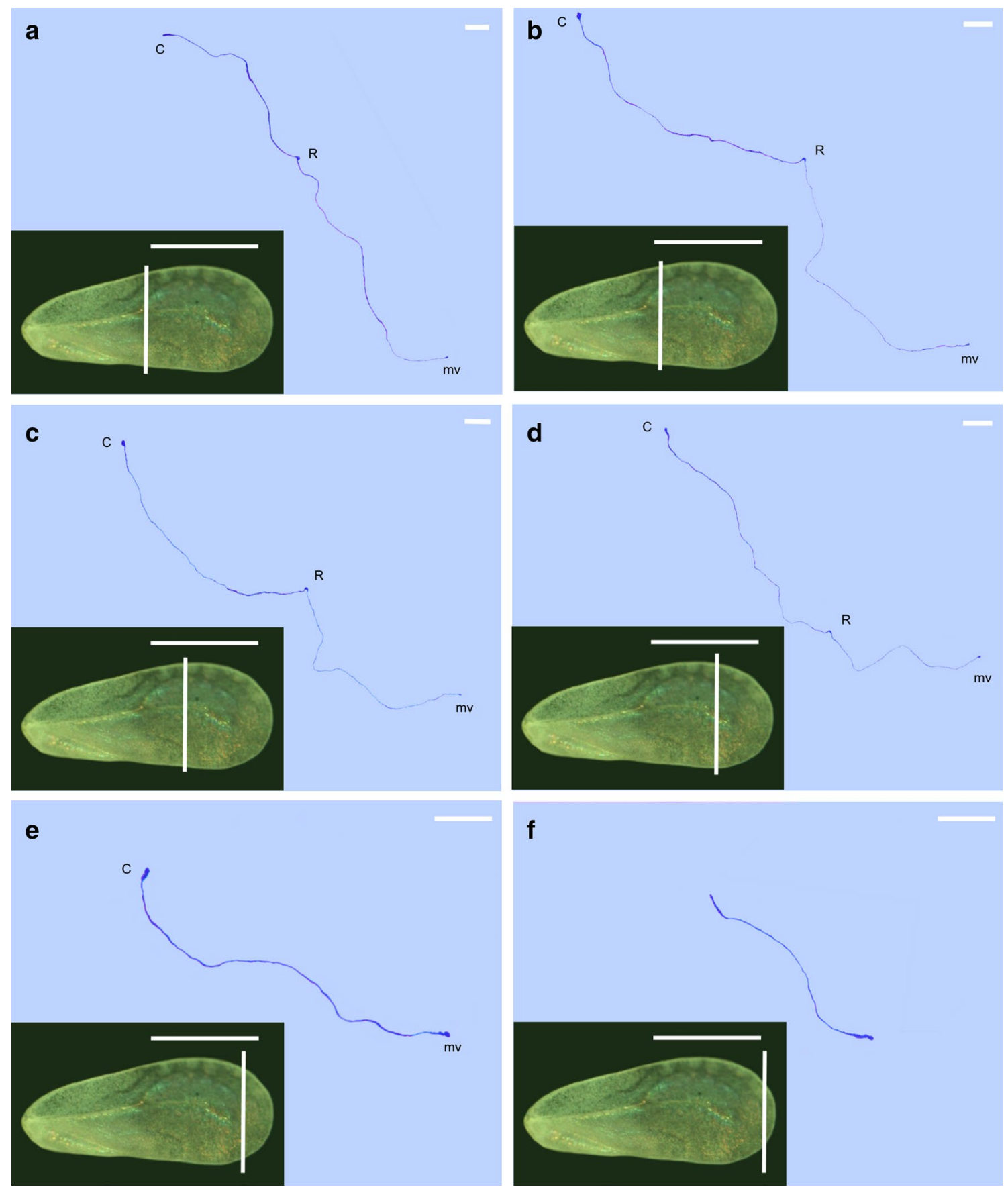

Fig. 4 Cross sections of the forewing of Aleyrodes proletella (Linnaeus 1758). LM scale bar $=500 \mu \mathrm{m}$. SEM scale bar $=50 \mu \mathrm{m}$

first branch of radial vein $\left(\mathrm{R}_{1}\right)$ present; 24(1): radial sector vein (Rs) present; 50(1): cervical sclerites reduced. The second group (coccoids + aleyrodids) is also monophyletic, which is confirmed by three synapomorphies: 5(1): medial vein (M) absent; 11(1): cubital anterior vein $(\mathrm{CuA})$ absent; 25(1): pterostigma absent.

\section{Forewing base articulation in Sternorrhyncha}

Schematic drawings of the wing base articulation (Fig. 7) are based on detailed analysis of species examined under LM and SEM. These photos are the part of our comparative 

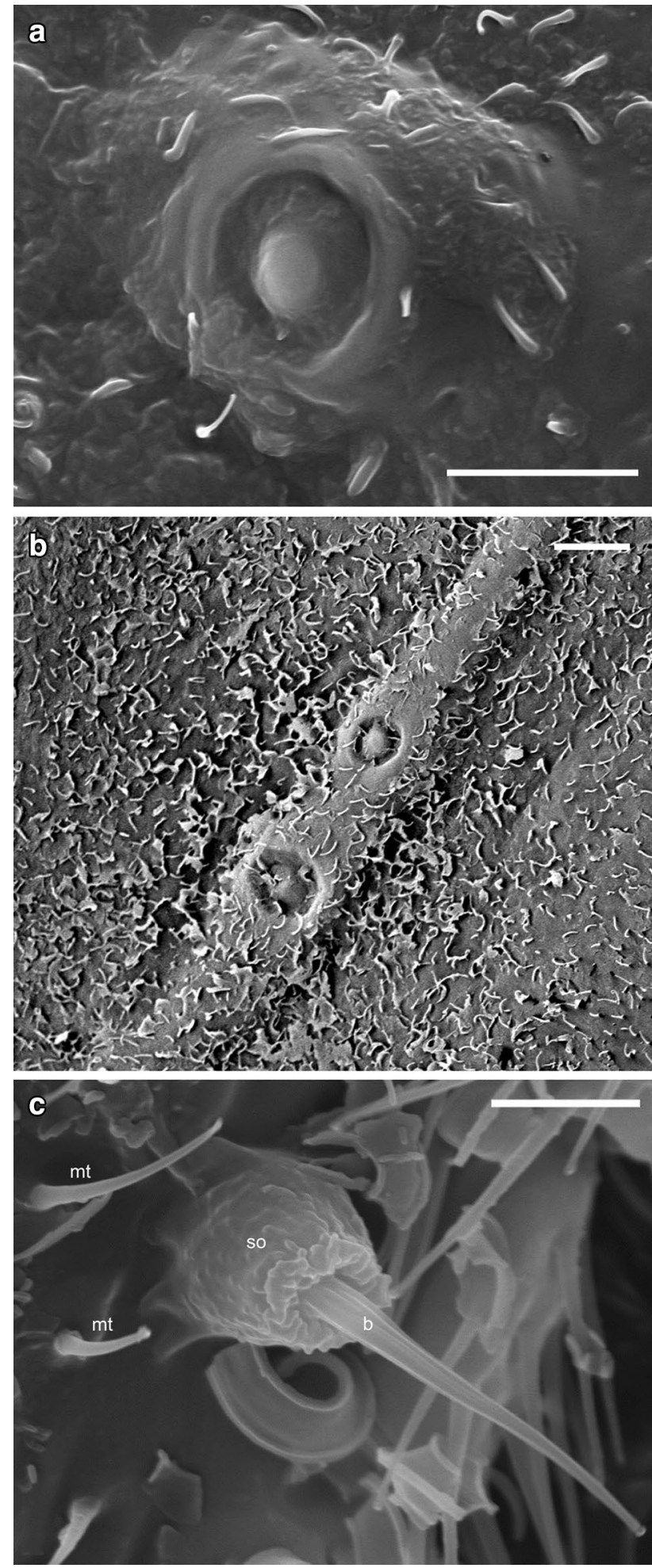

Fig. 5 Scanning electron microscopy: a campaniform sensillum near the wing base. Scale bar $5 \mu \mathrm{m}$ b two campaniform sensilla along the course of radial vein. Scale bar $10 \mu \mathrm{m}$, $\mathbf{c}$ trichoid sensillum on dorsal surface of the forewing; so socket, $b$ bristle, $m t$ microtrichium. Scale bar $2.5 \mu \mathrm{m}$
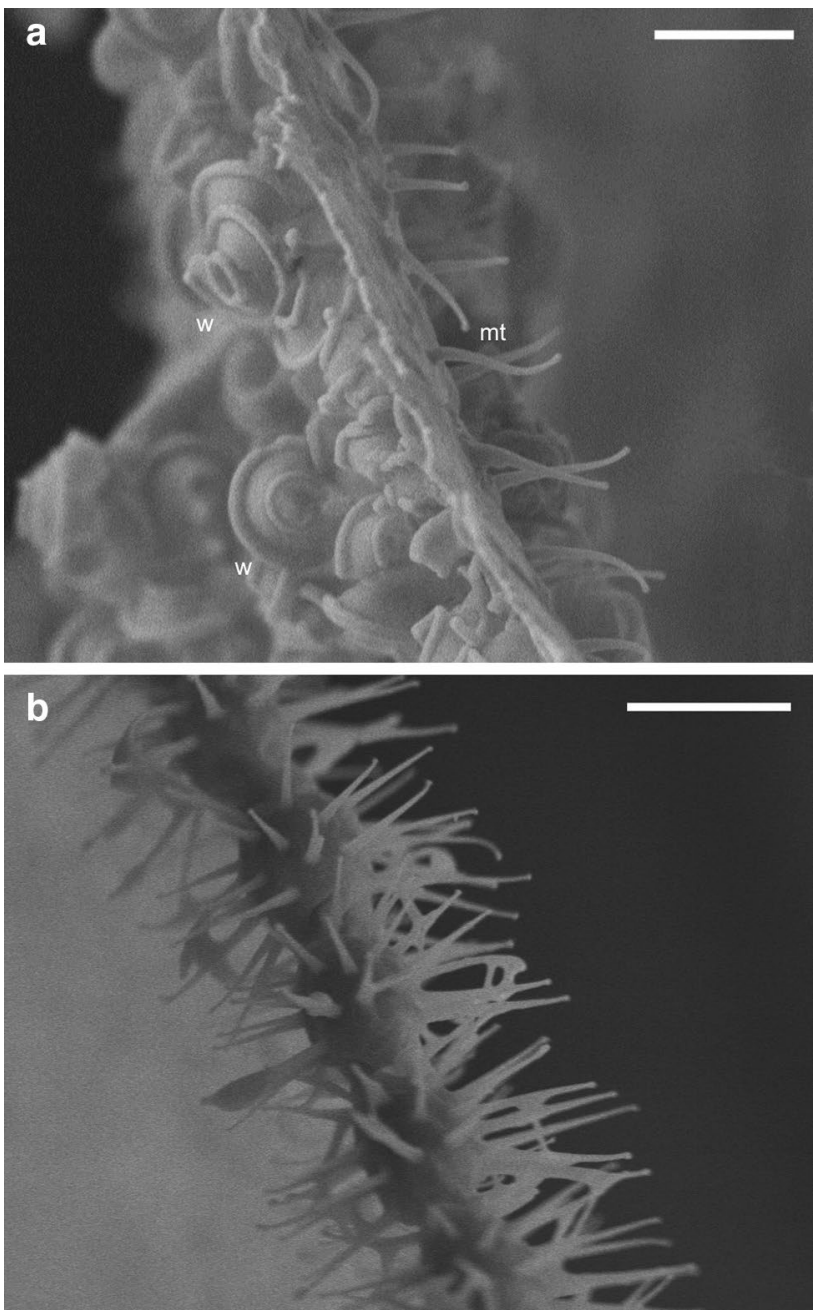

Fig. 6 Scanning electron microscopy: a wax shape; $w$ wax, $m t$ microtrichium. Scale bar $2.5 \mu \mathrm{m}, \mathbf{b}$ thickened margin of the forewing. Scale bar $5 \mu \mathrm{m}$

work about wing base in Sternorrhyncha (Franielczyk and Wegierek 2016). All figures were made in dorsal view of the wing base.

\section{Forewing veins in Sternorrhyncha}

Schematic drawings of the wing venation (Fig. 8) are based on detailed analysis of examined species (LM and SEM analysis). These photos are the part of our previous articles about forewings in aphids (Franielczyk-Pietyra and Wegierek 2017), psyllids (Franielczyk-Pietyra and Wegierek 2019) and coccoids (Franielczyk-Pietyra et al. 2018b). All figures were made in dorsal view of the wing surface. 
a
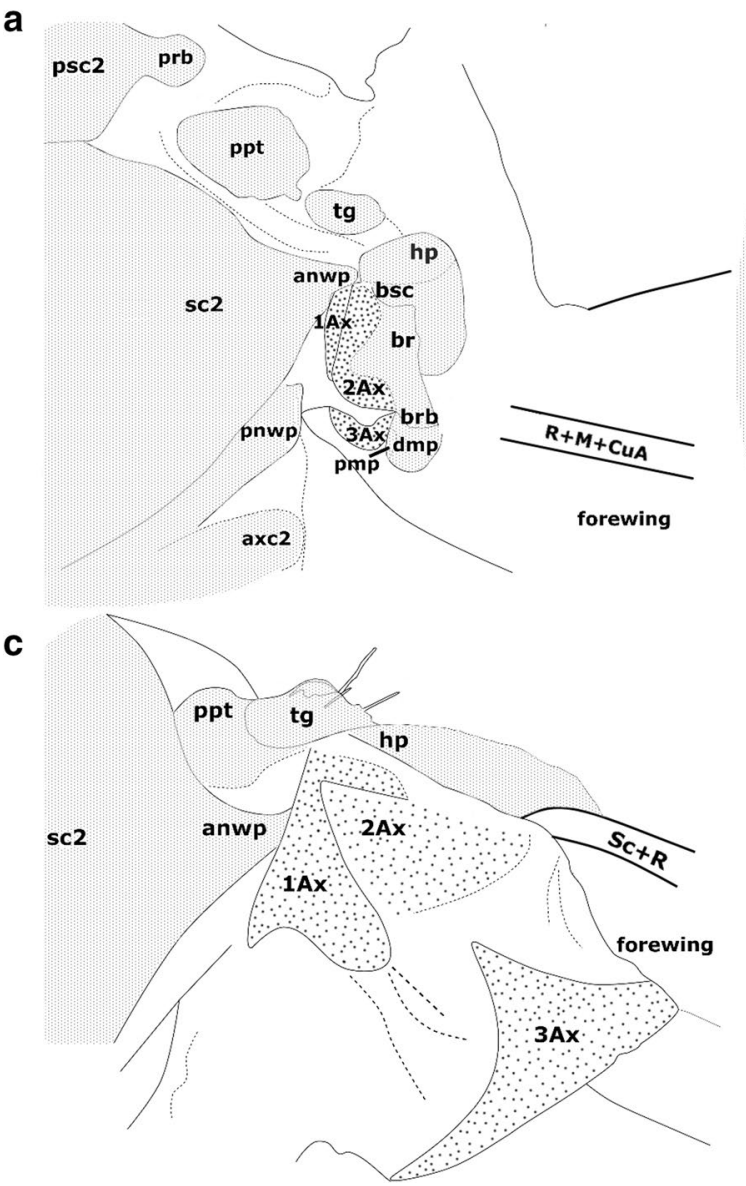

Fig. 7 Forewing base schematic drawings of all studied Sternorrhyncha representatives: a Cacopsylla mali; b Aphis fabae; c Orthezia urticae; $\mathbf{d}$ Aleyrodes proletella. $1 \mathrm{Ax}, 2 \mathrm{Ax}, 3 \mathrm{Ax}$ first, second and third axillary sclerites; anwp-anterior notal wing process; axc2-axillary cord; br-basiradiale; brb—basiradial bridge; bsc—basisubcos- b
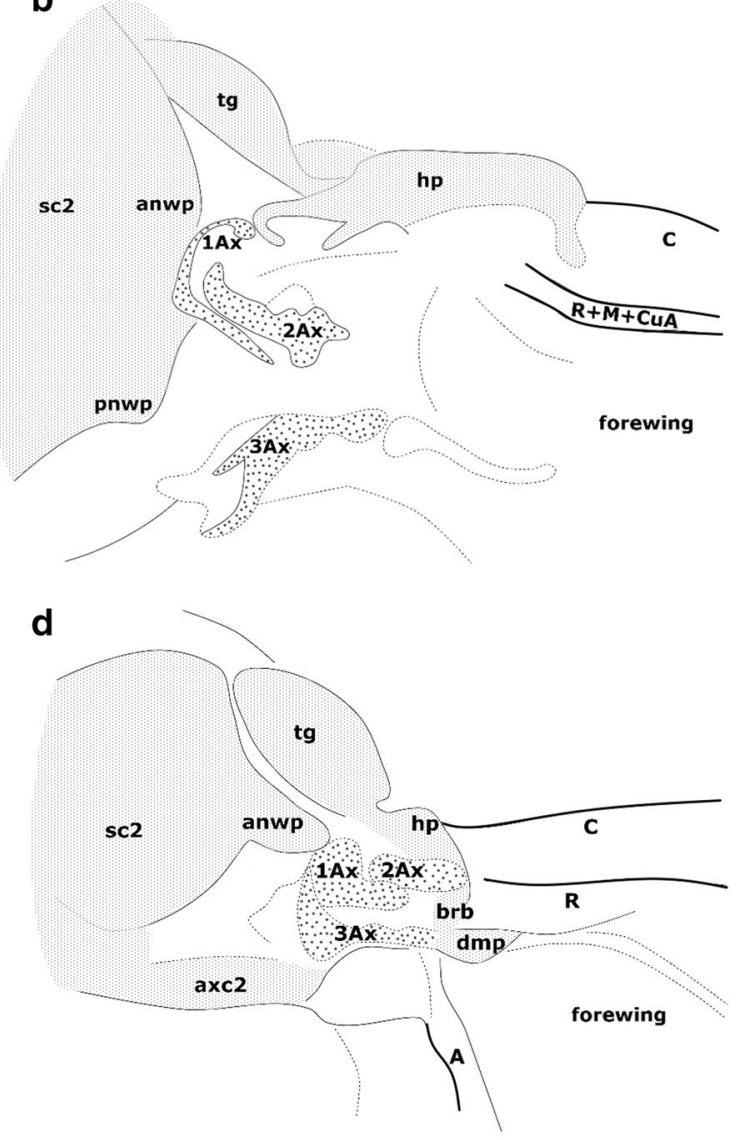

tale; dmp—distal median plate; hp—-humeral plate; pmp—-proximal median plate; pnwp - posterior notal wing process; ppt-parapterum; prb-prealar bridge; psc2 - praescutum; sc2-mesoscutum; tg-tegula; veins: $\mathrm{C}$-costal; $\mathrm{R}$-radial; $\mathrm{Sc}+\mathrm{R}$-fused subcostal and radial vein. Proportions not retained

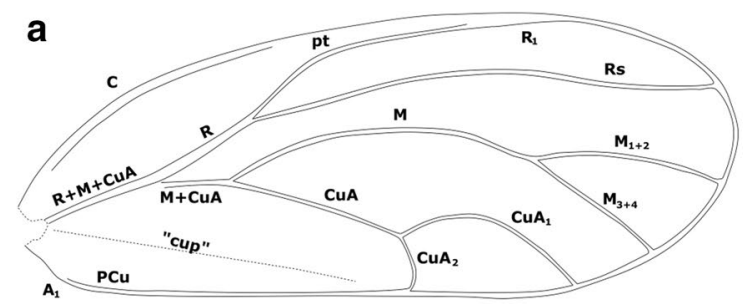

b
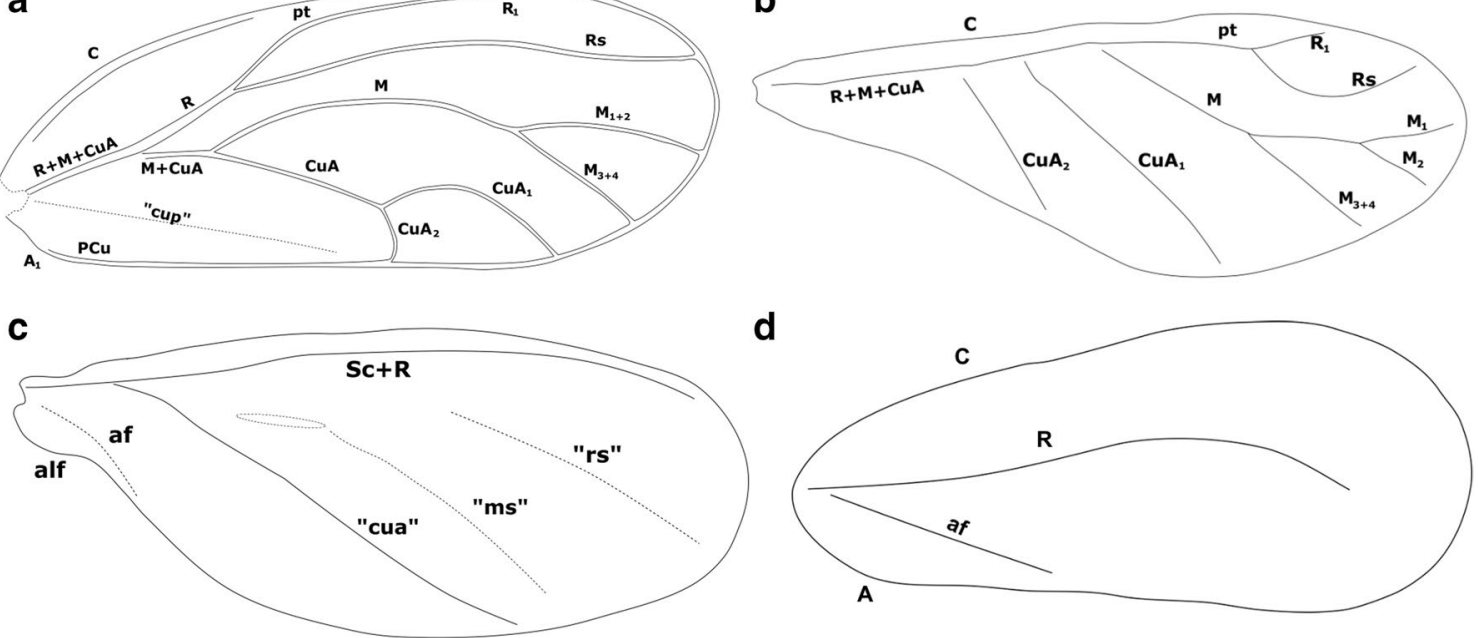

d

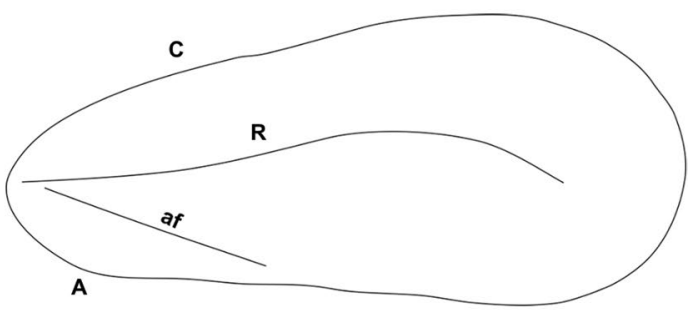

Fig. 8 Forewing schematic drawings of all studied Sternorrhyncha representatives: a Cacopsylla mali; b Aphis fabae; c Orthezia urticae; d Aleyrodes proletella. All abbreviations mentioned in "Materials and methods" section. Proportions not retained 


\section{Discussion}

\section{The forewing surface of $A$. proletella}

Campaniform sensilla can detect deformations of the surrounding cuticle caused by touch or air flow so they are involved in monitoring of wings movements (Chapman 2013). They function as proprioceptors responding to strains in the exoskeleton (McIver 1975; Yack 2004; Chapman 2013). In A. proletella, there are a few campaniform sensilla at the beginning of radial vein and some more along its course. In turn, trichoid sensilla can act as mechano-or chemoreceptors depending on the number of neurons connected to them (Shields 2010; Chapman 2013). As mechanoreceptors they can detect touch or vibrations of the air. Without them, the insect body cannot respond to mechanical stimuli (Page and Matheson 2004). According to current results, trichoid sensors are mostly confined to the veins and only a few sensilla of this kind are found on the dorsal surface of the whitefly wing.

\section{The forewing venation in A. proletella}

The wing venation of the studied species is considerably simplified compared to the oldest whitefly, Udamoselis pigmentaria (Udamoselinae) Enderlein, 1909. That was a particularly primitive whitefly, which had a relatively complex wing venation and a big body size (Shcherbakov 2000). As stated by Patch (1909) and Quaintance and Baker (1913), in the forewing of Aleyrodes sp. all tracheae are present but some veins became obsolete. In the forewing of extant whiteflies, especially from the Aleyrodes genus, one central vein, thickened marginal veins and the anal fold can be seen. Both the number of veins and the wing size are reduced. Primitive whiteflies had larger bodies and wings compared to extant species. For example, $U$. pigmentaria: body length $7 \mathrm{~mm}$, forewing length $5.5 \mathrm{~mm}$ (Martin 2007), while A. proletella: body length $1.3 \mathrm{~mm}$, forewing length $1.5 \mathrm{~mm}$ (current study). It can be stated that the reduction of wing venation is correlated with the decrease in both the body and the wing sizes (Byrne 1988; Žanić et al. 2001; Martin 2007).

The wing is strengthened by the amount of wax and thickening of wing margin, as there are two marginal veins and only one is placed in the center. Thickening of the wing margin is visible only under SEM and on cross sections and, using the methods available at that time, Klimaszewski and Wojciechowski (1992) could not detect it. They also denied the occurrence of costal vein, but as shown in the sections, it is present on the costal edge.
The cubital vein is apparently absent, but the anal fold is present. It cannot be interpreted as a cubital vein, as it is only a small indentation in the wing membrane, without a tunnel for hemolymph and nerves or tracheas inside. As mentioned earlier, as long as the anal fold is present, the anal vein can be traced in sections. Neither can the presence of medial vein be confirmed. On wing surface, right above the radial vein, there is a faint track, which can be mistaken for the first branch of radial vein $-R_{1}$. According to Martin (2007), members of the Aleyrodinae subfamily, where A. proletella belongs, often lack a forked radial. Therefore, central vein should be described as $R$, rather than $\mathrm{R}+\mathrm{Rs}$. In the histological part of the current study branching of this vein has not been confirmed, so this faint track is in fact only a thinner wax covering in this part of the wing. It may be a residue of $R_{1}$ tracheae, as suggested by Patch (1909). Unfortunately, we cannot agree with Patch's scheme of wing veins for A. proletella, where she marked central vein as Rs. If the radial vein has no branches, it should be referred to as radial along its entire course.

\section{A comparison of forewing characters in all examined Sternorrhyncha}

\section{The covering of the forewing}

Wax covering of the body of Sternorrhyncha representatives is varied and depends on the life stage. Immatures of all infraorders secrete wax which covers their bodies and that protective layer may differ in shape and wax amount. In adult forms, wings and some body parts are dusted with wax (Gullan and Martin 2009). This hydrophobic layer may protect from humidity or UV radiation and must be constantly supplemented. In Sternorrhyncha wax also prevents from contamination with honeydew, which is continuously dropped out by immatures and adults (Lucchi and Mazzoni 2004). Honeydew can smother the insect and promote microbial growth on or near the insect (Mittler and Douglas 2003).

Wings of coccid (Franielczyk-Pietyra et al. 2018b) and aleyrodid mature forms are covered most densely with wax. In coccoids, the layer of wax is produced by various epidermal glands which are scattered on the body surface (Foldi 1991; Koteja 1996; Gullan and Martin 2009). In aleyrodids, later instars and adults are covered by powdery wax (Gullan and Martin 2009). It is produced by wax glands on the ventral side of the 3-6th abdominal segments and distributed by legs over the whole body except eyes, antennae and genital organs (Weber 1935). Despite using different methods, no wax glands have been found on forewings of Sternorrhyncha in the current studies. 
Within Sternorrhyncha, wing surface is covered by various structures (Gullan and Martin 2009). Psyllids are typically endowed with numerous spines and papillae, as well as stripes resembling scratches but only several hairs (Klimaszewski 1975; Franielczyk-Pietyra and Wegierek 2019). Among coccoids, only neococcoids have short hairs (microtrichia); in the primitive groups of archeococcoids, these structures are absent, except for a few fossil families (Grimaldiellidae, Electrococcidae, Phenacoleachiidae) (Koteja and Azar 2008). Besides, the wing membrane can be tuberculate, as in Orthezia urticae Linné 1758 (Koteja 1986; Franielczyk-Pietyra et al. 2018b) or have folds like in Matsucoccidae (Koteja 1986). In aphids, short outgrowths resembling scales and ring-like elements along veins are present (Franielczyk-Pietyra and Wegierek 2017). Finally, aleyrodids have many smoothly terminating microtrichia which cover the whole wing (Figs. 5c, 6a). The presence of microtrichia on both sides of the wing, as in A. proletella, is not a common feature among insects. In Sternorrhyncha, these hairs are present only on the wings of aleyrodids, neococcoids and in a few fossil groups of coccoids. Instead, both types of hairs, micro-and macrotrichia, occur in water insects and protect them from water absorption. Species with wax-covered wings, like representatives of aleyrodids, usually have smooth surface of these hairs. This is in contrast to those without wax covering where the lack of wax is compensated by nanoarchitecture of both types of hairs (Watson et al. 2011).

Hypothesis 1 Morphologically flight apparatus does not differ much among Sternorrhyncha infraorders.

Forewing formation may have proceeded independently in these four groups (Franielczyk and Wegierek 2016, 2017, 2019; Franielczyk-Pietyra et al. 2018a, b). It is reflected by both axillary sclerites and the differences between forewing surface.

The wing base in $C$. mali (Fig. 7a) has most axillary sclerites and additional elements (Fig. 7a) and that of $A$. proletella has almost as many (Fig. 7d). A large number of additional components in psyllids are probably correlated with flight abilities; alike thorax muscles, they may also be correlated with precise jumping abilities (Gullan and Martin 2009; Burrows 2012). On the contrary, in examined aphids (Fig. 7b) and coccoids (Fig. 7c), wing base is relatively simple, with a small number of components. In conclusion, the similarities between forewing bases justify the statement that two groups, aphids + coccoids and psyllids + whiteflies have similar construction of this body region. It is congruent with morphological studies mentioned at the beginning and confirms the first hypothesis. However, in details, there are some minor differences showing independent ways of their development, which is shown in schematic drawings of wing bases (Fig. 7).

Hypothesis 2 Forewing external veins reflect their internal structure.

Both psyllids (Fig. 8a) and aphids (Fig. 8b) have wings supported by the largest number of veins, which are large in cross section (psyllids) (Franielczyk-Pietyra and Wegierek 2019) or covered by ring-like elements (aphids) (Franielczyk-Pietyra and Wegierek 2017). On the contrary, coccoids (Fig. 8c) and whiteflies (Fig. 8d) have very few veins, which are not additionally supported. In coccoids, it can be suggested that short-living males do not need a highly developed vein network. But forewings in both coccoids and whiteflies are strongly covered by wax, which is probably enough to strengthen wings. Based on forewing venation, again two groups can be distinguished, but this time different ones: psyllids are more similar to aphids, and coccoids to whiteflies. Detailed analyses of forewings can show differences referring not only to the number of veins, but also to their arrangement, branching, reaching or not the wing margin as well as to their cross section (Franielczyk-Pietyra and Wegierek 2017, 2019; Franielczyk-Pietyra et al. 2018a).

The costal vein is always present in all studied insects, except for $O$. urticae. In this species, the subcostal vein is confirmed (Fig. 8c). However, there is only one common vein among all examined species-the radial vein (Fig. 8). It occurs in three various arrangements. In coccoid species, it builds a common stem, along with the subcostal vein (Fig. 8c). In C. mali (Fig. 8a) and A. fabae (Fig. 8b), it is divided into two branches- $\mathrm{R}_{1}$ and Rs. Whereas in aleyrodids there is a single radial vein running almost through the center of the wing (Fig. 8d). In coccoids, there is only an indentation marked as "rs" (Fig. 8c). The medial vein is a part of the common stem in psyllids and aphids, while in coccoids it is reduced to a slight depression (marked as "ms" in Fig. 8c) and completely reduced in A. proletella (Fig. 8Dd). In psyllids and aphids branches of media are different. In the former, media bifurcates into fused $\mathrm{M}_{1+2}$ and $\mathbf{M}_{3+4}$ (Fig. 8a). In aphids, there are two separate branches$\mathrm{M}_{1}$ and $\mathrm{M}_{2}$ (fused at the beginning) and the third one$\mathrm{M}_{3+4}$ (Fig. 8b). Only one branch of the cubital vein, cubital anterior, is present in psyllids and aphids (Fig. 8a, b). The difference between these species consists in the fact that in $C$. mali $\mathrm{CuA}$ is a single vein which bifurcates into two branches- $\mathrm{CuA}_{1}$ and $\mathrm{CuA}_{2}$ (Fig. 8a), whereas in A. fabae these two branches depart straight, almost perpendicularly, from a common stem (Fig. 8b). What remains of this vein in $O$. urticae is only an indentation ("cua", Fig. 8c). The anal vein is observed only in the aleyrodid representative (Fig. 8d), while its first branch- $\mathrm{A}_{1}$ can be observed in 
psyllids (Fig. 8a). In the same species, as the only one, the postcubitus vein $(\mathrm{PCu})$ is observed (Fig. 8a).

Based on the current study, all described veins in psyllids and aleyrodids are true veins, as their cross sections have shown. In aphids, almost all veins can be confirmed as true ones, except for $\mathrm{R}_{1}$ (it is quite inconspicuous and hard to examine) (Franielczyk-Pietyra and Wegierek 2017), while in coccoids only the subcostal and radial are true veins. The remaining ones are only indentations without any light on the cross sections (Franielczyk-Pietyra et al. 2018b). This is the reason for rejecting hypothesis 2 .

\section{Veins layout}

When it comes to veins branching, in A. fabae (Scopoli 1763) (Franielczyk-Pietyra and Wegierek 2017), the common stem $\mathrm{R}+\mathrm{M}+\mathrm{CuA}$ is gradually divided into veins $\mathrm{CuA}_{2}$, $\mathrm{CuA}_{1}, \mathrm{M}, \mathrm{R}_{1}$ and Rs (Fig. 8b). In C. mali (Schmidberger 1836) (Franielczyk-Pietyra and Wegierek 2019), the common stem (also $\mathrm{R}+\mathrm{M}+\mathrm{CuA}$ ) is divided dichotomously - the first branch is $\mathrm{R}$ and the second $\mathrm{M}+\mathrm{CuA}$. Both branches are later divided into individual ones (Fig. 8a). A different condition is present in the forewings of $O$. urticae (Linnaeus 1758), where the common stem is composed of only two veins ( $\mathrm{Sc}$ and $\mathrm{R}$ ) and is not divided into any other veins (Franielczyk-Pietyra et al. 2018b). All other elements resembling veins have been confirmed to be only indentations in the wing membrane (Fig. 8c). In aleyrodid species presented here, the condition is most interesting: two marginal veins are present-the costal and anal ones (Fig. 8d). Also, in the central part of wing there is only the radial vein, so there is no common stem. It is a unique situation in the examined Sternorrhyncha; also, the presence of anal vein in whiteflies is unparalleled. In C. mali, only a short first branch of anal vein $\left(A_{1}\right)$ is confirmed (Franielczyk-Pietyra and Wegierek 2019).

\section{Wing coupling apparatus}

The wing coupling apparatus varies among Sternorrhyncha. In aphids, forewing develops a fold which is connected with the hamuli (hook-like hairs) of the hindwing (Franielczyk-Pietyra and Wegierek 2017). A similar condition is observed in coccoids. On the anal lobe of the forewing, a narrow fold is the place where hamuli attach (Franielczyk-Pietyra et al. 2018b). In psyllids (Franielczyk-Pietyra and Wegierek 2019) and in A. proletella, the wing coupling apparatus has the form of retinaculum. The current research confirms the presence of about 7 strong hairs on the hindwing; they may keep wings together during flight. In psyllids, there are more hindwing hairs than in aleyrodids (Quaintance and Baker 1913). As we can see, this wing element also confirms the usual grouping of aphids with coccoids and psyllids with aleyrodids.

The above relations between infraorders have been confirmed by the current results regarding forewing base articulation in Sternorrhyncha representatives (Franielczyk and Wegierek 2016). However, if combined with data from wing structures analysis (combined data summarized in Table 1), it suggests more similarities inside groups aphids + psyllids and coccoids + aleyrodids. These new relations have also been confirmed by consensus tree (Fig. 9). It may be explained by the fact that aphids and psyllids have less fragile wings than other two groups. Also, aphids are considered very good fliers and psyllids quite good jumping insects and strong wings improve this way of dispersion. Therefore, the number of wing veins and wing stiffness should not surprise in these two groups. On the contrary, coccoids (Gullan and Martin 2009) and aleyrodids are rather weak fliers, which is also reflected on the tree of similarities (Fig. 9). Additionally, after using 10 more characters regarding head and thorax structures, described relationships remained. Our phylogenetic grouping may be the result of convergency and should be taken with some caution.

Hypothesis 3 The way of wing folding (flat or roof-like) in Aphidomorpha infraorder is correlated with the structure of wing base.

Although the general model of axillary sclerites in wing base is similar among Sternorrhyncha infraorders, there are some differences between these elements among taxa within one infraorder. It is particularly evident in the detailed analysis of Aphidomorpha (Franielczyk-Pietyra et al. 2018a), where axillary sclerites of 24 aphid genera were described. The studies concentrated on aphids because these insects have different reproduction modes (viviparity and oviparity), as well as individual ways of wing folding. They are also easily accessible. It seems possible that various shapes of axillary sclerites are the result of environmental factors, but this hypothesis needs further verification. Studies showed that axillary sclerites are similar so the third hypothesis also was rejected. We can assume that the way of wing folding is determined by the thorax structure.

Summarizing, the authors have been able to confirm only the first initial hypothesis. However, it is with the indication that in spite of one general model of wing base, some differences in the number and shape of elements can be found. Two other assumptions have been rejected. As mentioned before, the internal structure of the wing base is not correlated with the way wings fold in Aphidomorpha. As for the veins, we have proved that external elements known as veins are not always compatible with cross sections. 
Table 1 Comparison on forewing veins, base articulation and main wings structures among Sternorrhyncha representatives

\begin{tabular}{|c|c|c|c|c|}
\hline Vein/structure & $\begin{array}{l}\text { Aphids } \\
\text { Aphis fabae }\end{array}$ & $\begin{array}{l}\text { Coccoids } \\
\text { Orthezia urticae }\end{array}$ & $\begin{array}{l}\text { Psyllids } \\
\text { Cacopsylla mali }\end{array}$ & $\begin{array}{l}\text { Aleyrodids } \\
\text { Aleyrodes proletella }\end{array}$ \\
\hline $\mathrm{C}$ & + & & + & + \\
\hline $\mathrm{Sc}$ & & + & & \\
\hline $\mathrm{R}$ & + & + & + & + \\
\hline $\mathrm{Sc}+\mathrm{R}$ & & + & & \\
\hline $\mathrm{R}_{1}$ & + & & + & \\
\hline Rs & + & Residue "rs" & + & \\
\hline M & + & Residue "ms" & + & \\
\hline $\mathrm{M}_{1}$ & + & & & \\
\hline $\mathrm{M}_{2}$ & + & & & \\
\hline $\mathrm{M}_{1+2}$ & + & & + & \\
\hline $\mathrm{M}_{3+4}$ & + & & + & \\
\hline \multicolumn{5}{|l|}{$\mathrm{Cu}$} \\
\hline $\mathrm{CuA}$ & + & Residue "cua" & + & \\
\hline $\mathrm{CuA}_{1}$ & + & & + & \\
\hline $\mathrm{CuA}_{2}$ & + & & + & \\
\hline A & & & & + \\
\hline $\mathrm{A}_{1}$ & & & + & \\
\hline Common stem & $\mathrm{R}+\mathrm{M}+\mathrm{CuA}$ & $\mathrm{Sc}+\mathrm{R}$ & $\mathrm{R}+\mathrm{M}+\mathrm{CuA}$ & \\
\hline $\mathrm{PCu}$ & & & Residue "cup" & \\
\hline anwp & + & + & + & + \\
\hline \multicolumn{5}{|l|}{ mnwp } \\
\hline pnwp & + & + & + & + \\
\hline $1 \mathrm{Ax}$ & + & + & + & + \\
\hline $2 \mathrm{Ax}$ & + & + & + & + \\
\hline $3 \mathrm{Ax}$ & + & + & + & + \\
\hline $\operatorname{tg}$ & + & + & + & + \\
\hline hp & + & + & + & + \\
\hline bsc & & & + & \\
\hline br & & & + & \\
\hline $\mathrm{dmp}$ & + & & + & + \\
\hline pmp & & & + & \\
\hline prb & & & + & \\
\hline brb & & & + & + \\
\hline ppt & & + & + & \\
\hline $\operatorname{axc} 2$ & + & + & + & + \\
\hline Pterostigma & + & & + & \\
\hline Marginal vein & & & + & + \\
\hline Wing coupling apparatus & + & + & + & + \\
\hline Anal lobe & & + & & \\
\hline Type of wing venation & $\begin{array}{l}\text { Separate veins leave } \\
\text { from a common stem }\end{array}$ & $\begin{array}{l}\text { Strongly reduced; only a } \\
\text { common stem present }\end{array}$ & A common stem bifurcates & $\begin{array}{l}\text { Veins } C \text { and } A \text { surround } \\
\text { the wing and } R \text { is placed } \\
\text { centrally }\end{array}$ \\
\hline Amount of wax & Small & Large & Small & Large \\
\hline
\end{tabular}




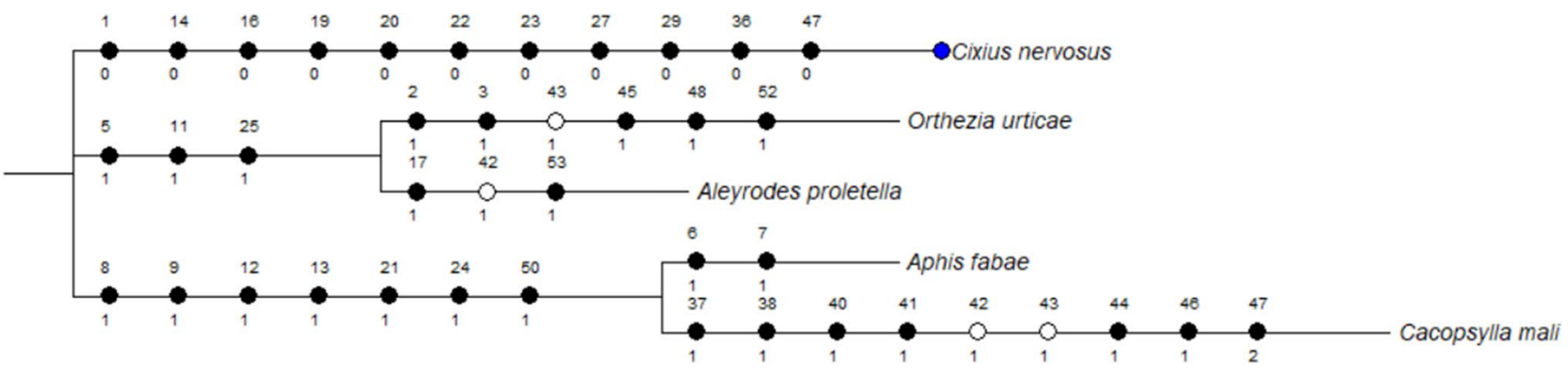

Fig. 9 Majority rule consensus tree. Black circles correspond to synapomorphies, white circles to homoplasies; numbers for characters correspond to those used in Appendices 1 and 2

Acknowledgements The authors are sincerely grateful to Dr. Danuta Urbańska-Jasik, University of Silesia, for cross sections of the wings and Dr. Jagna Karcz from Scanning Electron Microscopy Laboratory, University of Silesia, for taking pictures. We also wish to thank Dr. Marcin Walczak for help with data matrix. We appreciate all the critical comments and suggestions of Editor and anonymous Reviewers that improved the first version of the manuscript.

\section{Compliance with ethical standards}

Conflict of interest The authors declare that they have no conflict of interest.

Ethical approval All procedures performed in studies involving animals were in accordance with the ethical standards of the institution or practice at which the studies were conducted.

Human and animal rights We neither used endangered species nor were the investigated animals collected in protected areas. This article does not contain any studies with human participants performed by any of the authors.

Open Access This article is distributed under the terms of the Creative Commons Attribution 4.0 International License (http://creativeco mmons.org/licenses/by/4.0/), which permits unrestricted use, distribution, and reproduction in any medium, provided you give appropriate credit to the original author(s) and the source, provide a link to the Creative Commons license, and indicate if changes were made.

\section{References}

Burrows M (2012) Jumping mechanisms in jumping plant lice (Hemiptera, Sternorrhyncha, Psylloidea). J Exp Biol 215:3612-3621. https://doi.org/10.1242/jeb.074682

Byrne DN (1988) Relationship between wing loading, wingbeat frequency and body mass in homopterous insects. J Exp Biol 135:9-23

Carver M, Gross GF, Woodward TE (1991) Hemiptera. In: Naumann ID, Carne PB, Lawrence JF et al (eds) The insects of Australia. CSIRO/Melbourne University Press, Carlton, pp 429-509

Chapman RF (2013) The insects: structure and function, 5th edn. Cambridge University Press, Cambridge, pp 194-232

Drohojowska J, Szwedo J (2015) Early cretaceous aleyrodidae (Hemiptera: Sternorrhyncha) from the Lebanese amber. Cretac Res $52: 368-389$
Evans GA (2007) The whiteflies (Hemiptera: Aleyrodidae) of the world and their host plants and natural enemies. https://bugguide.net/ node/view/1198941. Accessed 06 April 2018

Foldi I (1991) The wax glands in scale insects: comparative ultrastructure, secretion, function and evolution (Hemiptera: Coccoidea). Ann Soc Entomol France 27:163-188

Franielczyk B, Wegierek P (2016) Comparative morphology of the forewing base articulation in Sternorrhyncha compared with a representative of Fulgoromorpha (Insecta, Hemiptera). Zoomorphology 135:89-101. https://doi.org/10.1007/s00435-015-0293-4

Franielczyk-Pietyra B, Wegierek P (2017) The forewing of the Aphis fabae (Scopoli 1763) (Hemiptera, Sternorrhyncha): a morphological and histological study. Zoomorphology 136:349-358. https:// doi.org/10.1007/s00435-017-0358-7

Franielczyk-Pietyra B, Wegierek P (2019) The forewing of Cacopsylla mali (Schmidberger 1836) (Hemiptera, Sternorrhyncha) — a morphological and histological study. Zool Anz 278:95-100. https:// doi.org/10.1016/j.jcz.2018.12.003

Franielczyk-Pietyra B, Bernas T, Sas-Nowosielska H, Wegierek P (2018a) Is there a relationship between the morphology of the forewing axillary sclerites and the way the wing folds in aphids (Aphidomorpha, Sternorrhyncha, Hemiptera)? Zoomorphology 137(1):105-117. https://doi.org/10.1007/s00435-017-0390-7

Franielczyk-Pietyra B, Depa Ł, Wegierek P (2018b) Morphological and histological study of the forewing of Orthezia urticae (Linnaeus 1758) (Hemiptera, Sternorrhyncha). Zookeys 747:101-114. https ://doi.org/10.3897/zookeys.747.23950

Goloboff P, Catalano S (2016) TNT, version 1.5, with a full implementation of phylogenetic morphometrics. Cladistics 32:1. https://doi. org/10.1111/cla.12160

Gullan PJ, Martin JH (2009) Sternorrhyncha (jumping plant-lice, whiteflies, aphids, and scale insects). In: Resh VH, Cardé RT (eds) Encyclopedia of insects, 2nd edn. Elsevier, San Diego, pp 957-967

Heie OE, Wegierek P (2009) A classification of the Aphidomorpha (Hemiptera: Sternorrhyncha) under consideration of the fossil taxa. Redia XCII:69-77

Hennig W (1981) Insect phylogeny. Wiley, New York

Hodges GS, Evans GA (2005) An identification guide to the whiteflies (Hemiptera: Aleyrodidae) of the southeastern United States. Florida Entomol 88(4):518-534

Kanturski M, Karcz J, Wieczorek K (2015) Morphology of the European species of the aphid genus Eulachnus (Hemiptera: Aphididae: Lachnidae) - a SEM comparative and integrative study. Micron 76:23-36

Klimaszewski SM (1975) Psylloidea. Koliszki (Insecta: Homoptera). Fauna Polski 3:1-295 
Klimaszewski SM, Wojciechowski W (1992) Relationship of recent and fossil groups of Sternorrhyncha as indicated by the structure of their forewings. Wydaw Uniw Śląskiego 1318:1-50

Koteja J (1986) Morphology and taxonomy of male Ortheziidae (Homoptera, Coccinea). Pol Pismo Entomol 56:323-374

Koteja J (1996) Scale insects (Hemiptera: Coccinea) a day after. In: Schaefer CW (ed) Studies on hemipteran phylogeny. Thomas Say Publications in entomology: proceedings. Entomol Soc Am, Lanham, pp 65-88

Koteja J, Azar D (2008) Scale insects from Lower Cretaceous amber of Lebanon (Hemiptera: Sternorrhyncha: Coccinea). Alavesia 2:133-167

Lucchi A, Mazzoni E (2004) Wax production in adults of planthoppers (Homoptera: Fulgoridea) with particular reference to Metcalfa pruinose (Flatidae). Ann Entomol Soc Am 97(6):1294-1298

Maddison WP, Maddison DR (2009) Mesquite: a modular system for evolutionary analysis. Version 2.71. http://www.mesquiteproject .org

Martin JH (2007) Giant whiteflies (Sternorrhyncha, Aleyrodidae): a discussion of their taxonomic and evolutionary significance, with the description of a new species of Udamoselis Enderlein from Ecuador. Tijdschr Entomol 150:13-29

Martin JH, Mifsud D, Rapsidara C (2000) The whiteflies (Hemiptera: Aleyrodidae) of Europe and the Mediterranean Basin. Bull Entomol Res 90:407-448

McIver SB (1975) Structure of cuticle mechanoreceptors of arthropods. Ann Rev Entomol 20:381-397

Mittler TE, Douglas AE (2003) Honeydew. In: Resh VH, Carde RT (eds) Encyclopedia of insects. Academic Press, San Diego, pp 523-525

Nel A, Prokop J, Nel P, Grandcolas P, Huang D-Y, Roques P, Guilbert E, Dostál O, Szwedo J (2012) Traits and evolution of wing venation pattern in paraneopteran insects. J Morphol 273:480-506. https://doi.org/10.1002/jmor.11036

Nixon KC (2002) WinClada ver. 1.00.08; Ithaca, New York

Page KL, Matheson T (2004) Wing hair sensilla underlying aimed hindleg scratching of the locust. J Exp Biol 207:2691-2703. https ://doi.org/10.1242/jeb.01096

Patch EM (1909) Homologies of the wing veins of the Aphididae, Psyllidae, Aleurodidae and Coccidae. Ann Entomol Soc Am 2:101-135

Quaintance AL, Baker AC (1913) Classification of the Aleyrodidae Part I. Technical series. US Dep Agric Bureau Entomol 27:1-93
Schlee D (1970) Verwandtschaftsforschung an fossilien und rezenten Aleyrodina (Insecta, Hemiptera). Stutt Beitr Naturkd 213:1-72

Shcherbakov DE (2000) The most primitive whiteflies (Hemiptera; Aleyrodidae; Bernaeinae subfam.nov.) from the Mesozoic of Asia and Burmese amber, with an overview of Burmese amber hemipterans. Bull Br Mus Nat Hist Geol 56(1):29-37

Shcherbakov DE (2007) Extinct four-winged precoccids and the ancestry of scale insects and aphids (Hemiptera). Russ Entomol J 16(1):47-62

Shields VDC (2010) High resolution ultrastructural investigation of insect sensory organs using field emission scanning electron microscopy. In: Mendez-Vilas A, Diaz J (eds) Microscopy: science, technology, application and education. Formatex Research Center, Badajoz, pp 321-328

Szelegiewicz H (1971) Cechy autapomorficzne w budowie skrzydeł Sternorrhyncha (Hemiptera) i ich znaczenie dla oceny paleozoicznych przedstawicieli tej grupy pluskwiaków. Ann Zool XXIX 2:15-81

Szwedo J, Drohojowska J (2016) A swarm of whiteflies-the first record of gregarious behavior from Eocene Baltic amber. Sci Nat 103:1-35. https://doi.org/10.1007/s00114-016-1359-y

Szwedo J, Nel A (2011) The oldest aphid insect from the middle triassic of the Vosges, France. Acta Palaeontol Pol 56:757-766. https ://doi.org/10.4202/app.2010.0034

Watson JA, Cribb BW, Hu H-M, Watson GS (2011) A dual layer hair array of the brown lacewing: repelling water at different length scales. Biophys J 100:1149-1155

Weber H (1935) Der Bau der Imago der Aleurodinen. Ein Beitrag zur vergleichenden Morphologie des Insektenkorpers. Zoologica 89. E. Schweizerbart'sche Verlagsbuchhandlung (Erwing Nagele). Stuttgart

Wegierek P (2002) Relationships within Aphidomorpha on the basis of thorax morphology. Wydawnictwo Uniwersytetu Śląskiego, Katowice

Yack JE (2004) The structure and function of auditory chordotonal organs in insects. Microsc Res Tech 63:315-337

Žanić K, Kačić S, Katalinić M (2001) Duhanov štitasti moljac Bemisia tabaci (Gennadius, 1889) (Homoptera: Aleyrodidae) u Hrvatskoj. Entomol Croat 5(1-2):51-63

Publisher's Note Springer Nature remains neutral with regard to jurisdictional claims in published maps and institutional affiliations. 